\title{
D. PEDRO NA EUROPA: UMA NOVA ESPERANÇA PARA OS LIBERAIS PENINSULARES
}

\author{
Braz Augusto Aquino Brancato*
}

Passados os primeiros momentos da instauraçao do Império brasileiro começaram a aparecer as divergências entre as diferentes facçбes políticas, apesar de terem um ideal comum: concretizar e afirmar a independência brasileira.

Como é conhecido, gradualmente, o Imperador ia granjeando, no Brasil, cada vez mais opositores ao autoritarismo que exercia, graças aos termos em que a Carta Outorgada havia sido concebida. Aos poucos a popularidade que alcançara durante a Regência, principalmente nos momentos que precedem a separação política do Brasil de Portugal, foi sendo perdida e, para tal, concorreu não só o autoritarismo que the era imputado, mas também o surgimento do que se poderia denominar de o "problema português" ou a "questão portuguesa".

Efetivamente, depois de conhecida no Brasil a notícia da morte de D. João VI de Portugal, o temor de que, mais uma vez, o Brasil se visse ligado politicamente a este Reino se apresentava. No entanto, a "questao portuguesa" se revigorou no Brasil, depois que D. Miguel, já como "lugar-tenente"1 de D. Pedro, retornou de Viena para Lisboa, particularmente quando aquele se fez aclamar rei de Portugal, ${ }^{2}$ assumindo, assim, a Coroa que D. Pedro havia reservado à sua filha Maria da Glória. A partir desta nova situaçao aumentavam os temores dos brasileiros de que seu Imperador estivesse mais interessado nos problemas da Coroa lusitana do que nos do Brasil.

$\mathrm{Na}$ realidade tais temores procediam, pois D. Pedro foi obrigado a envolver-se mais diretamente com os negócios portugueses. Em conseqüência adotou algumas medidas no sentido de defender os direitos de sua filha e, para tal, teve que utilizar, por exemplo, a diplomacia brasileira para realizar os contatos internacionais necessários. Foi esta preocupação com a Coroa portuguesa que fez com que muitos brasileiros temessem que, novamente, os assuntos de um e outro Estado se misturassem e, parecia mais, D. Pedro ainda estaria alimentando a esperança de manter as duas Coroas, nao faltan- 
do, até mesmo, aqueles que lhe acusassem de seguir sendo um "português" e de rodear-se, principalmente, de lusitanos.

$\mathrm{O}$ ambiente no Brasil era bastante tenso nos primeiros meses de 1831 , e tal situação foi aproveitada por aqueles que propugnavam por uma série de reformas políticas, tendentes a dar a Carta Outorgada um cunho mais liberal, implantando no país um verdadeiro parlamentarismo, o que implicava em diminuir o "poder pessoal" do Imperador. Por outro lado, o enfrentamento entre o Imperador e os Deputados crescia perigosamente.

Este estado de tensão alcançou seu grau máximo no dia 5 de abril daquele ano, quando D. Pedro substituiu o Ministério, afastando, assim, do poder, políticos que, embora ño procedessem propriamente das fileiras da oposição liberal exaltada, tampouco eram homens comprometidos com o "autoritarismo". 3

Destituindo o Ministério, logo nomeou outro integrado por velhas figuras do Império ${ }^{4}$ que contrastavam com os ministros depostos: brasileiros identificados com a causa nacional. Além disto, o novo Ministério era considerado anti-liberal, o que contribuiu para aumentar sua impopularidade. Frente a problema de tal dimensão D. Pedro, depois de infrutíferas tentativas de contornar a situação, decidiu abdicar da Coroa imperial. Assim, em 7 de abril de 1831, concluía o primeiro reinado do Império do Brasil, produzindo-se o que Joaquim Nabuco, com muita propriedade, chamou de "um desquite amigável entre o Imperador e a Naçao".5 Abria-se então, nao só uma nova etapa para a história brasileira, mas também para a portuguesa e para o próprio liberalismo ibérico.

A decisao de $\mathrm{D}$. Pedro I de abdicar a Coroa imperial tem sido vista por alguns autores como um ato vinculado à possibilidade de vir reunir, sob seu cetro, os dois reinos ibéricos. Na verdade, esta possibilidade foi cogitada por liberais peninsulares na época da Abdicação, o que leva Joaquim Nabuco a afirmar que tais acontecimentos teriam servido para "impor subitamente a D. Pedro I uma solução que já estava aceita por ele e para a qual lhe faltava somente combinar as últimas providências e escolher o momento". ${ }^{6}$

De qualquer forma, sobre este problema nos parece que nao se pode descartar a possibilidade de que à hora de tomar tão importante decisão, como a de abdicar a Coroa do Brasil, D. Pedro tenha se lembrado dos convites que, neste sentido, tinha recebido de liberais peninsulares. Seguir este caminho seria tornar realidade um sonho que tantos outros reis ibéricos haviam acalentado antes dele. Contudo, até o presente momento, qualquer afirmação neste sentido não passa de mera especulação, sem possibilidade de comprovação.

Mas, o que é certo e, interesse destacar aqui, é que a abdicação de D. Pedro I no Brasil, foi uma verdadeira injeção de novas forças para aqueles 
que lutavam pela restauração do regime constitucional, quer em Portugal quer na Espanha, ao mesmo tempo em que enchia de preocupaçбes os Governos de Lisboa e Madri.

A notícia da abdicação do Imperador do Brasil, tão logo chegou a Europa, produziu uma imediata reação por parte das autoridades peninsulares que viam um verdadeiro perigo no fato de que $\mathrm{D}$. Pedro houvesse deixado o Brasil para dirigir-se ao Velho Continente.

Segundo o visconde d'Asseca, que tratava, oficiosamente, dos negócios do Portugal miguelista em Londres, as notícias sobre a abdicação do Imperador do Brasil começaram a circular naquela capital em 8 de junho, um dia antes de que o navio Volage, que transportava o Imperador - agora usando o título de duque de Bragança - chegasse ao porto de Falmouth. ${ }^{7}$

$\mathrm{O}$ visconde d'Asseca tratou, imediatamente, de comunicar o acontecimento ao governo de D. Miguel, enviando of ício ao visconde de Santarém ${ }^{8}$ em que participava também o temor que tal notícia tinha produzido no representante diplomático espanhol junto à Corte de St. James. Assim escrevia o diplomata português:

"Este tão extraordinário como importante acontecimento pareceu ao Ministro de S.M. Catholica de natureza a ser comunicado ao seu Governo com a maior brevidade e para isso pediu ao Seu Governo para the facilitar hum meio de mandar hum correio a alguns portos da Corunha e espera que hoje mesmo o paquete que deve ir a Cadiz regularmente toque em algum d'aqueles portos, e eu aproveito esta occasião que me parece ser a de fazer mais prontamente ao conhecimento de V. Ex. esta participação."

O mesmo visconde d'Asseca, enviou outro ofício ao visconde de Santarém, ${ }^{9}$ confirmando, nos seguintes termos, a grande preocupação que tinha causado a abdicação e a chegada de D. Pedro à Europa:

"Julgo que o Governo de Sua Magestade estará informado dos espantosos acontecimentos que tiverão logar no Rio de Janeiro e da abdicação do Imperador, assim como a chegada de S.M. a Europa. O navio Daupine, ou Treze de Maio..., deve ter chegado a Lisboa, e por ele... os detalhes de tal catastrophe para a causa Monarchica. $A$ influencia que o facto pode ter sobre os interesses de Portugal hé de tal modo complicada, que não me atrevo a adiantar a minha oppiniāo." [O grifo é nosso]

$\mathrm{Na}$ realidade, a viagem de $\mathrm{D}$. Pedro, há tanto temida, agora se efetivava e não passava desapercebido a ninguém que, se de um lado a resistência antimiguelista da ilha Terceira se via fortalecida, por outro, os refugiados, tanto portugueses como espanhóis, recebiam um novo e poderoso impulso 
para reacender, na península Ibérica, a chama revolucionária. O conde de Ofalia, representante espanhol em Paris, manifesta claramente esta preocupação, em ofício "reservadísimo" que enviou a D. Manuel González Salmón, Secretário de Estado de Fernando VII. ${ }^{10}$ Neste ofício, comunicando a cheģada do duque de Bragança e Cherbourg diz:

"...no teniendo aquí correo de Gabinete que despachar, me valgo de uno de los de aguardo para remitir á V.E. estos pliegos. Como la carta no 424 en que doy cuentas á V.E. de la llegada del ex = Emperador $\mathrm{D}^{\mathrm{n}}$ Pedro á Cherbourg estaba preparada $\mathrm{p}^{\mathrm{a}}$ poder ir $\mathrm{p}^{\mathrm{r}}$ el correo ordinario á falta de otra proporcion; no he entrado en muchas reflexiones sobre el peligro que puede amenazar al Portugal y á la Peninsula de resultas de la venida de $\mathrm{D}^{\mathrm{n}}$ Pedro á Europa; pero la penetracion de V.E. conocerá que este peligro, aúnque no tan grande, á mi entender como lo decantan ya los revolucionarios, es sinembargo digno de nucha consideracion." [O grifo é nosso]

Com o duque de Bragança na Europa abria-se uma nova fase na luta dos liberais contra o absolutismo de D. Miguel, bem como para os exilados espanhóis que seguiam tentando derrubar Fernando VII do poder.

No que respeita a Portugal é importante ter presente que, a partir de sua chegada no continente europeu, D. Pedro passava a poder fazer-se cargo, pessoalmente, da defesa dos direitos de sua filha. Além disto, podia também assumir as funçбes de Regente do Reino, o qual tinha que reconquistar, já que apenas permaneciam fiéis a Dna. Maria II aqueles que tinham formado, na ilha Terceira, um núcleo de resistência e uma Regência. Esta Regência, embora confirmada por D. Pedro quando ainda estava no Brasil, não tinha conseguido, até então, ajuda suficiente para poder fazer periclitar o Governo do "usurpador"

Os primeiros momentos depois da chegada de D. Pedro à Europa foram difíceis. De uma parte, os exilados esperavam que o ex-Imperador do Brasil aportasse o dinheiro necessário para poder organizar um ataque efetivo ao território lusitano peninsular. De outra parte, o duque de Bragança tinha o natural receio em comprometer sua fortuna pessoal em tal empresa sem um detido exame da situação. ${ }^{11}$ Também era necessário estabelecer contatos com os reis da França e da Gra-Bretanha para ver até que ponto Dna. Maria II podia contar com o apoio daquelas Naçðes.

Neste contexto se tem que ter em conta que na França e na Gra-Bretanha a situação parecia ser mais favorável à causa dos liberais. Na primeira se havia instalado a "Monarchie de julliet" e na segunda se produzira uma mudança do Gabinete tory de Wellington pelo whig de Grey, Palmerston e Holland, o que fazia com que fosse mais fácil conseguir o apoio a causa de 
Maria II, que era também a causa dos liberais contra o absolutismo miguelista.

D. Pedro, uma vez na Europa, deveria fixar, como tutor de Dna. Maria da Glória, os rumos da luta pelos direitos desta. Apesar de não deter a função de Regente, que seguia sendo exercida pela Regência da Terceira, parece evidente que ele era o interlocutor mais adequado para tratar junto às Cortes de Paris e de Londres os assuntos relativos à restauraçđo de Maria II no trono lusitano.

Tudo indica que o contato direto de D. Pedro com os Monarcas da França e da Gra-Bretanha seria muito mais eficiente e fácil do que para a Regência da Terceira, através de seus representantes diplomáticos acreditados junto àquelas Cortes. Isto é provado pela maneira como o ex-Imperador foi recebido em ambas. ${ }^{12}$

De qualquer forma D. Pedro nao decidiu imediatamente, depois de chegar a Cherbourg, qual a orientação definitiva que daria à sua vida e de que maneira participaria na campanha contra D. Miguel. Esta demora na tomada de uma decisão chegou a impacientar alguns portugueses que defendiam a volta de Portugal a uma Monarquia Constitucional.

No entanto, depois de uma série de contatos e preparativos, D. Pedro resolveu assumir, pessoalmente, a direção da luta pela restauração de sua filha no trono português e, com tal objetivo, em 10 de fevereiro de 1832 partiu de Belle-Isle à frente de uma expedição que rumou para os Açores. Uma vez no arquipélago foi organizado o ataque ao território peninsular que culminaria, finalmente, com a derrota de D. Miguel selada com a assinatura do Tratado de Évora-Monte (25/5/1834).

A luta pela restauração de Maria II teve um especial interesse também para os liberais espanhóis, embora não tivessem, estes, intervido diretamente nela - ao menos em atividades bélicas propriamente ditas - devido ao acordo feito por D. Pedro com a França e com a Grá-Bretanha no intuito de conseguir a neutralidade, ao menos formal, do Governo da Espanha. Tal interesse, como é natural, residia no fato de que uma vitória de D. Pedro sobre D. Miguel representava uma vitória do constitucionalismo em Portugal. Para os exilados espanhóis, esta vitória se configuraria, obviamente, numa nova oportunidade de conseguir dar um novo vigor às tentativas de restaurar, também na Espanha, o regime constitucional que Fernando VII duas vezes havia derrubado. Mais ainda, quem sabe nao conseguiriam fazer com que D. Pedro, agora, aceitasse efetivamente o trono espanhol e, até mesmo ser rei, ou imperador, de toda a península Ibérica?

$O$ retorno de D. Pedro a Europa já não era mais uma mera expectativa: se havia concretizado e, com isto, passava a ser uma esperança mais próxima para os liberais que apostavam nele como o caminho para o restabele- 
cimento constitucional. Em sentido inverso, ele deixara de representar, para o Governo de Fernando VII, apenas um perigo distante, para transformarse num problema sério e próximo.

Como vimos, o conde de Ofalia, desde Paris, em ofício datado de 13 de junho de 1831 , preocupado com a chegada de D. Pedro, analisava os perigos que tal ocorrência representava para a Espanha, destacando que D. Pedro deveria, segundo sua opinião, ao invés de hostilizar a D. Miguel, apoiá-lo, e que o mais sensato de sua parte seria tratar de casar Dna. Maria da Glória com D. Miguel, conforme o que anteriormente havia sido previsto. ${ }^{13}$ Porém, o próprio conde de Ofalia, neste ofício, destaca que isto não ocorreria, indicando que D. Pedro, em função de

"...su caracter altanero y ambicioso: la adulacion de los refugiados Portugueses y Españoles, que le buscaron como instrumento para turbar la tranquilidad de la Península, lisongeádose con que haciendose dueño de Portugal puede llegar á serlo de toda la Península...: las maquinaciones del partido exaltado de Francia y de la sociedades secretas, que le apadrinaran como medio para propagar las ideas revolucionarias en la Península y comprometer al actual Ministerio Frances: la coincidencia de su venida con los preparativos y expedicion de Francia para hostilizar al Sr. $D^{\mathrm{n}}$. Miguel.... ${ }^{14}$ la impasibilidad que en tan graves circunstancias muestra hasta ahora el Ministro Inglés á la vista de la crisis que amenazará al Portugal; son cosas todas reunidas para dar el mayor cuidado y exigir de nuestra parte la mayor actividad y vigilancia."

Ofalia vai ainda mais longe em suas preocupações com respeito à presença de D. Pedro na Europa. No mesmo ofício indicado informava ter falado com o Ministro francês, Sébastiani, sublinhando que:

“...si por medio de D. Pedro se turbaba la tranquilidad de Portugal puede correr riesgo la de la Peninsula; que turbada esta la dominacion misma de Luis = Felipe en Francia corre peligro, pues los exaltados no olvidan que es Borbon, y si llegan a adquirir ascendiente le lanzaran tambien como á Carlos $\mathrm{X}$, para entablar sus sofiados planes de república: que por consiguiente el Ministerio actual..., debe contrarrestar las maquinaciones de que $\mathrm{D}^{\mathrm{n}}$. Pedro puede ser autor ó instrumento y apresurarse á una reconsiliacion con $\mathrm{D}^{\mathrm{n}}$. Miguel que consolide la tranquilidad de la Peninsula..."

O Embaixador espanhol em Paris, diplomata de larga experiência, em seu extenso ofício de dez folhas, deixa transparecer, a todo momento, sua preocupaçao pelo que poderia vir a ocorrer na península Ibérica no caso de que a conspiração liberal fosse vitoriosa em Portugal. Se pode observar que procura, por todos os meios, conseguir aquilo que lhe parecia o mais conve- 
niente para Fernando VII, insistindo, até mesmo, em colocar o Governo francês contra a derrubada de D. Miguel.

Tal preocupação, como é lógico, foi aumentando na medida em que se via que o duque de Bragança estava decidido a intervir, pessoalmente, na luta contra D. Miguel e, mais ainda, quando a expedição, que se preparava para sair de Belle-Isle, passou a ser conhecida com mais detalhes. Neste sentido, o ativo representante espanhol em Paris logo que obteve maiores informações tratou de informar ao Secretário de Estado, D. Manuel González Salmón, através do ofício "muy reservado", do dia 18 de dezembro de $1831 .^{15}$

O interesse por parte das autoridades espanholas com relaçao ao assunto era perfeitamente compreensível se tivermos em conta que a chegada de D. Pedro a Europa trazia consigo um novo alento para a conspiraça liberal contra o trono de Fernando VII, como bem o demonstra uma carta do marquês de Rezende ao conde do Lavradio, enviada de Cherbourg em junho de 1831. ${ }^{16}$ Segundo esta carta, o General Saldanha havia transmitido a D. Pedro que os Generais Espoz y Mina e Torrijos com seus partidários queriam que o ex-Imperador do Brasil assumisse a Coroa espanhola.

Como se pode ver, D. Pedro ao deixar o Brasil estava abrindo novas perspectivas para os revolucionários peninsulares que passavam a contar com um novo impulso para tentar conseguir fazer com que Espanha e Portugal, novamente, vivessem uma Monarquia constitucional.

\section{NOTAS}

1 - D. Miguel foi nomeado "Lugar-tenente" de D. Pedro IV através do Decreto do dia 3 de julho de 1827.

2 - D. Miguel, depois de praticar uma série de atos tendentes a restaurar o absolutismo em Portugal, conseguiu ser proclamado, oficialmente, "rei de Portugal e dos Algarves" no dia 11 de julho de 1828.

3 - Paula BEIGUELMAN. Formação Politica do Brasil, São Paulo, Livraria Pioneira Editora, 1976. p.48.

4 - O novo Ministério nomeado pelo Imperador estava integrado pelos marqueses e Inhambupe, Paranaguá, Baependi, Aracati, Lages e pelo visconde de Alcântara.

5 - Um Estadista do Império, v.I, São Paulo, Instituto Progresso Editorial, 1949, p.25. 
6-Op. cit., p.27.

7 - Desde este porto seguiu para a França, chegando a Cherbourg no dia seguinte.

8 - 20 Visconde de SANTARÉM. Correspondência do..., v.IV. Lisboa, Alfredo Lamas Motta \& Ca L $^{\text {da }}$ Editores, 1918, p.92-3 (Ofício do dia 10 de junho de 1831).

9 - Ibidem, p.75-6 (Ofício do dia 15 de junho de 1831).

10 - Archivo del Ministerio de Asuntos Exteriores (Madrid), Legajo 2616. Portugal-Política, 1830/31.

11 - Convém lembrar que D. Pedro herdou de seu pai um grande apego aos bens materiais. Otávio Tarquínio de SOUSA ( $A$ Vida de D. Pedro I, in: História dos Fundadores do Império, v.IV, t.III, Rio de Janeiro, Livraria José Olympio Editora, 1957, p.944 e ss.), apresenta uma série de dados relativos a atividade de $\mathrm{D}$. Pedro a bordo do navio inglês Warspite, antes de partir do Rio de Janeiro, que demonstra seu trabalho na liquidação dos negócios e bens que tinha no Brasil. Tratava o ex-Iperador de arrecadar a maior quantia possível de dinheiro para levar consigo, uma vez que não podia contar com os bens que possuía em Portugal.

12 - Exemplo disto é o relato que Luís Antônio de Abreu e Silva, representante da Regência da Ilha Terceira em Londres, enviou a Luís da Silva Mousinho de Albuquerque sobre o contato mantido por D. Pedro com o Monarca britânico. No ofício de 2 de julho de 1831 (Arquivo Nacional da Torre do Tombo - Lisboa - MNE, Maço 98, Livro 74 Arquivo da Legação Português em Londres - "Ofícios reservados" 1830/34), se pode ler: “...Lord Palmerston| que no mesmo dia da chegada de S.M. tinha vindo assinar o seu nome no livro das visitas veio no dia seguinte encarregado de uma mensagem de S.M.B. pa o Imperador, que exprimindo o sentimento de El Rei por differir a recepção de S.M.I. até o dia 29 em razao de se achar ausente em Windor, fixando aquella recepção para as duas horas daquelle dia no Palacio de S. James, e convidando a S.M.I. para assistir a um concerto na mesma noite, e um baile no dia 30 , e uma janta no dia 1 o do corrente." E segue mais adiante informando que "El Rei recebeu primeiramente, S.M.I. no seu Gabinete particular, e depois dos primeiros cumprimentos, tendo-se retirado as demais pessoas, ficarao ambos sós por bastante tempo."

13 - Esta solução seria a mais favorável para a Espanha, uma vez que, ao mesmo tempo em que afastaria o perigo de que D. Pedro assumisse a Coroa lusitana e desde Portugal ameaçasse Fernando VII, também 
garantia o trono de D. Miguel já que, se efetivando o casamento, a Gra-Bretanha o reconheceria como rei de Portugal e, a este reconhecimento, certamente, se seguiriam outros.

14 - Refere-se ao episódio relativo à atitude do Governo de Lisboa com relaçao a cidadðos franceses em Portugal, considerada hostil pelo Governo francês. Este Governo enviou uma esquadra, comandada pelo Almirante Roussin, que entrou no Tejo para formular uma série de exigências ao Governo de D. Manuel. (Sobre estes fatos veja-se, entre outros: Paulo THUREAU-DANGIN, Histoire de la Monarchie de Julliet, v.I, Paris, Librairie Plon, 1884, p.399-400 e J.P. de Oliveira MARTINS, Portugal Contemporâneo, v.I, Porto, Lello \& Irmão Editores, 1981, p.234-7).

15 - Archivo del Ministerio de Assuntos Exteriores (Madrid), Legajo 2617, Portugal - Política, 1831.

16 - Conde de LAVRADIO. Op. cit., p.11.

Nesta carta o marquês de Rezende se refere aos dois grupos de maneira depreciativa, dizendo que "fallou ainda o Saldanha para dizer que toda a minaria e torrijania queria Sua Magestade para Rei da Hespanha..."

Observação: Todas as citaçðes guardam a grafia original.

* Departamento de História

Pontifícia Universidade Católica do Rio Grande do Sul

Porto Alegre-RS 